\title{
Design of a Support Program for Energy Efficiency Improvement in Latvian Industry
}

\author{
Kristīne Dobrāja ${ }^{1}$, Līga Ozolinga ${ }^{2}$, Marika Rošăa ${ }^{3},{ }^{1-3}$ Riga Technical University
}

\begin{abstract}
The aim of this paper is to assess the voluntary agreement for increasing energy efficiency in industry of Latvia and provide recommendations for more effective implementation in the future. Energy efficiency in Latvian industry and data monitoring of the CCFI (Climate Change Financial Instrument) subprogram "Complex solutions to reduce greenhouse gas emissions in production facilities" is analyzed. An evaluation of the voluntary agreement is given and outlines suggestions for more effective implementation of the Latvian program to achieve the defined energy reduction targets for industry.
\end{abstract}

Keywords - energy efficiency, Latvian industrial sector, voluntary agreement

\section{INTRODUCTION}

One of the biggest energy consumers in the world is the industrial sector. Energy efficiency has an important role to improve environmental sustainability, energy security and economic indicators in the industrial sector. It is possible to stimulate and promote policy-makers to make decisions that promote energy efficiency improvements by introducing energy efficiency policy. According to the European Union (EU) directives on energy efficiency, Member States are required to introduce measures that increase energy efficiency.

Energy efficiency can be promoted through a variety of instruments and measures in the industrial sector such as voluntary agreements with industry associations, tax incentives for particular industries, cooperation/programs, emissions trading, energy consumption reduction targets, energy audits, subsidies, tax concessions, etc.

Energy-saving target of Latvian industrial sector as well as the energy efficiency measures to achieve the target is defined in the First Latvian Energy Efficiency Action Plan (NEAP). Additional measures to fulfil the aim for industry were included and described in the Second NEAP of Latvia and they are as follows: Complex solutions to reduce greenhouse gas emissions in industrial buildings (The Climate Change Financial Instrument (CCFI)), the voluntary agreement for energy efficiency improvement by supporting industrial energy audits and energy management systems for companies.

The CCFI sub-program "Complex solutions to reduce greenhouse gas emissions in industrial buildings" is one of the main measures to achieve the energy-saving target of the Latvian industrial sector. Therefore, it is important to evaluate the sub-program and to find the solutions on how to improve the energy efficient measures. It could be possible to come closer to the target of 2016 and 2020 by evaluating and improving the program. If the target for the industrial sector will not be achieved with the CCFI sub-program, it is necessary to introduce the second measure in the form of a voluntary agreement which was set in NEAP.

The voluntary agreement program for companies "Regulations Regarding the Procedures for Entering into and Supervision of an Agreement Regarding Energy Efficiency Improvement" in Latvia entered into force on 15 July, 2011. However, the current situation shows that the voluntary agreement program is not designed completely and complications may occur if the program is operating in practice. The Ministry of Economy is responsible for the program.

Therefore this paper presents an insight of energy efficiency in the Latvian industrial sector and an evaluation of the CCFI sub-program "Complex solutions to reduce greenhouse gas emissions in industrial buildings" and the existing voluntary agreement program. In the conclusions, the suggestions and proposals for effective implementation of the program in Latvia are presented.

\section{ASSESSMENT OF ENERGY EFFICIENCY IN LATVIAN INDUSTRIAL SECTOR}

The industrial sector is the third largest energy endconsumer in Latvia. The energy consumption of the industrial sector on average is $32 \mathrm{PJ} / \mathrm{year}$ over the last 5 years. The implementation of energy efficiency measures will lead to reduction of energy consumption in Latvian industry. Therefore it is essential to look at the breakdown of the sector as well as the number and size of enterprises and their energy efficiency performance [1].

\section{A. Breakdown of industry sector}

Industrial sector is divided into three sub-sectors: mining and quarrying, construction and manufacturing. Each of the sub-sectors includes a variety of industries that are classified taking into account the NACE Rev. 2 classification [2].

According to the Central Statistical Bureau of Latvia, there were 15106 economically active statistical units (selfemployed persons, commercial companies, sole proprietorships, agricultural and fishing farms) in industrial sector in 2010. In total 7881 are representing the manufacturing industry, 7015 construction and only 210 mining and quarrying. In this paper the main focuses on direct enterprise activities - commercial companies. An enterprise is considered any economic activity subject, regardless of its legal form $[1,3]$.

According to the Central Statistical Bureau of Latvia, the number of enterprises and distribution by the size group in 2010 are represented in Table I. 
Micro, small and medium-sized enterprises (SMEs) play a vital role in the economy. However, they are often confronted with shortcomings by affecting the development of production which results in reduced access to new technologies and innovations. Therefore, SMEs should be supported to promote the development of industrial growth [6].

TABLE I

DISTRIBUTION OF COMMERCIAL COMPANIES IN MINING AND QUARRYING, MANUFACTURING AND BUILDING SECTORS DOWN BY SIZE GROUPS [3]

\begin{tabular}{|l|c|c|c|}
\hline & $\begin{array}{c}\text { Mining and } \\
\text { quarrying }\end{array}$ & Manufacturing & Construction sector \\
\hline Micro & 122 & 4260 & 4507 \\
\hline Small & 48 & 1364 & 1081 \\
\hline Medium & 7 & 418 & 218 \\
\hline Large & 2 & 59 & 20 \\
\hline Total & 179 & 6101 & 5826 \\
\hline
\end{tabular}

\section{B. Energy consumption in Latvia}

The Latvian industry, including construction, mining and manufacturing, consumes around $18 \%$ of the final energy consumption in Latvia (Fig. 1) [1].

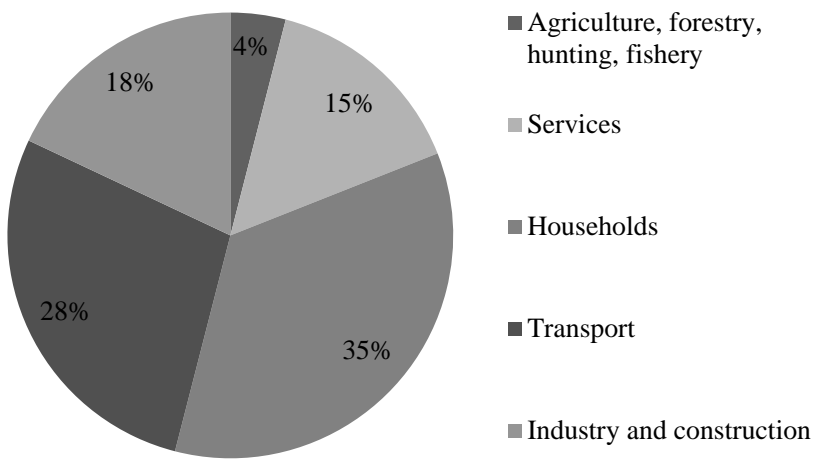

Fig. 1. Final energy consumption in sub-sectors in 2010 [1]

Out of 32 PJ, around $89 \%$ of energy resources are consumed by the manufacturing industry. Therefore, there should be more attention paid to the processing industry. It is important to determine what amount of energy is consumed to produce a certain unit of production, and how effective is that production [1].

\section{Energy efficiency policy in the industrial sector}

The first official document which was attributed to the improvement of energy efficiency in the Latvian industrial sector was the First Latvian Energy Efficiency Action Plan 2008 - 2010 followed by the Second Latvian Energy Efficiency Action Plan 2011 - 2013. Developing the First and Second NEAP the target was set as 159 GWh energy savings in the industrial sector by 2016 . The target $159 \mathrm{GWh}$ is around $2 \%$ of the final energy consumption in the industrial sector. The greatest emphasis in the First NEAP is put on the dissemination of information on energy efficient lighting and technologies instead of on the promotion of real energyreduction measures such as energy-efficient equipment and energy management system implementation. It was concluded that energy savings in the industrial sector was not achieved by developing the Second NEAP $[1,3,7]$.

\section{EVAlUATION OF THE SUB-PROGRAM OF THE ClimATE CHANGE FINANCIAL INSTRUMENT}

The sub-program "Complex solutions to reduce greenhouse gas emissions in industrial buildings" is granted financial support for energy efficiency measures. It aims to reduce greenhouse gas emissions, improve energy efficiency in industrial buildings and industrial technologies (equipment).

The total planned energy reduction within this program is 159 GWh until 2016. In total 49 contracts were signed for the renovation of industrial building during the project. At the moment the energy efficiency measures have been implemented only in 39 enterprises. The indicator for the project evaluation to obtain the support was set as $\mathrm{CO}_{2}$ emissions per $\mathrm{kg}$ of project eligible costs (Ls). The project activities were aimed at improving energy efficiency in the industrial sector which would be in the form of investments to improve energy efficiency in manufacturing processes or energy management systems. The co-financing was granted for industrial building renovation (insulation) despite the generally accepted energy performance conditions. From this it can be concluded that the project activities were more focused on building energy efficiency policies rather than on the main aspects of energy efficiency in the industrial sector $[7,9,10]$.

\section{A. An evaluation of the first monitoring period}

During 2012 there was a evaluation of the CCFI subprogram "Complex solutions to reduce greenhouse gas emissions in industrial buildings". The evaluation was based on the monitoring results to find out the total energy made as a result of implementing the subprogram [10].

The first monitoring report was for the period from $1^{\text {st }}$ September 2011 to $31^{\text {st }}$ December 2011, and the reports had to be submitted until $31^{\text {st }}$ January 2012. Contacting the Latvian Environmental Investment Fund (LEIF), which is the responsible organization for the monitoring of CCFI, it was discovered that only four out of 48 monitoring reports were submitted by February, 2012. It appears that five enterprises had refused to participate in the subprogram. Consequently, only 43 enterprises were involved in the subprogram. The total energy savings would be only $29 \mathrm{GWh}$ achieved by 2016 if all 43 enterprises will fulfill all the energy saving measures that were calculated in the energy audits. The expected energy savings were $34 \mathrm{GWh}$ if all the 48 enterprises fulfill all the energy efficiency measures. The evaluation of four monitoring reports concluded that only two enterprises had decreased energy consumption and only one of them can be taken into account. Further research was based on A/S "Rigas Piena Kombinats" (milk product producing company) monitoring data where $72.8 \%$ of the expected energy savings per month were reached. Based on these data it was assumed that the rest of the enterprise will also reach around $73 \%$ of energy savings. That means the total energy savings would be only 
$21 \mathrm{GWh}$ in 2016 which would be only $13 \%$ of energy savings that were set in the First NEAP [10].

\section{B. An evaluation of the first full monitoring period}

Once again contacting with LEIF in April, 2013, it was ascertained that only 11 enterprises out of 37 submitted monitoring reports for the period from $1^{\text {st }}$ January 2012 to $31^{\text {st }}$ December 2012. The monitoring reports had to be submitted on $31^{\text {st }}$, January 2013, and eight of eleven monitoring reports were approved. The other three were re-examined and revised. Currently there are 39 enterprises from 48 that have participated in the sub-program and have completed or almost completed the projects. Consequently, the total energy savings may change compared to calculations after the first period of monitoring. The calculated energy savings could vary based on the fact that the monitoring reports of 2011 were only for three months and implemented energy efficiency measures had not yet shown their full potential [9].

\section{Energy savings for the year 2012}

The evaluation of the second monitoring period was based on the results of eight monitoring report data in order to evaluate the obtained energy savings by implementing the CCFI subprogram (see Table I). There were shortcomings identified in the achieved energy savings in one of the eight monitoring reports, therefore only seven monitoring reports are discussed further.
As can be seen in Table II, the enterprises which had submitted their monitoring reports for the full year have achieved energy and $\mathrm{CO}_{2}$ emission savings. It should be noted that most of the implemented measures are related to energy efficiency in industrial buildings, respectively - building insulation. Only two of seven monitoring reports include information on energy efficiency measures for the change of manufacturing equipment.

It can be observed that enterprises have been able to meet and exceed the energy and $\mathrm{CO}_{2}$ savings compared with the planned (Fig.2., Fig.3.).

The enterprises which submitted their monitoring reports for the full year have achieved energy and $\mathrm{CO}_{2}$ emission savings. The average difference between planned and achieved results of $\mathrm{CO}_{2}$ emission savings is $\sim 55 \%$ greater than expected between 7 companies. The average energy savings between 7 enterprises is $\sim 50 \%$ more than planned. Changes in the volume of production could be one of the explanations for the big difference between planned and achieved energy savings, because in the monitoring reports the volume of production was not required. Declining manufacturing amount causes reduction of energy consumption and $\mathrm{CO}_{2}$ emissions which is not associated with a reduction of energy by introduced energy efficiency measures. The changes in the volume of production should be taken into account to accurately determine the energy savings through energy efficiency measures.

TABLE II

REVIEW OF ENERgY SAVINGS IN THE 2012 PERIOD

\begin{tabular}{|c|c|c|c|c|}
\hline No. & The name of the beneficiary & Measures to increase the energy efficiency (EE) & The achieved energy savings (MWh) & Reduction of $\mathrm{CO} 2, \mathrm{t}$ \\
\hline 1 & Ltd. "TTS-AVIO" & $\begin{array}{l}\text { EE improvement of industrial buildings and } \\
\text { technological equipment }\end{array}$ & 784,273 & 168,13 \\
\hline 2 & $\begin{array}{c}\text { Ltd. "MAGNAT } \\
\text { PROJECT } \\
\text { MANAGEMENT" }\end{array}$ & Improving EE in the building manufacturing & 1837,739 & 602,55 \\
\hline 3 & Ltd. "KMM Metāls" & Improving EE in the building manufacturing & 472,851 & 95,043 \\
\hline 4 & Ltd. "ZETA" & Improving EE in the building manufacturing & 972,341 & 256,698 \\
\hline 5 & Ltd. "NORDIC PLAST" & $\begin{array}{c}\text { Reconstruction of processing line - EE } \\
\text { improvement }\end{array}$ & 1330,34 & 528,14 \\
\hline 6 & Ltd."4 PLUS" & Improving EE in the building manufacturing & 562,113 & 159,132 \\
\hline 7 & Ltd. "FIRMA JATA" & Improving EE in the building manufacturing & 117,557 & 31,035 \\
\hline
\end{tabular}




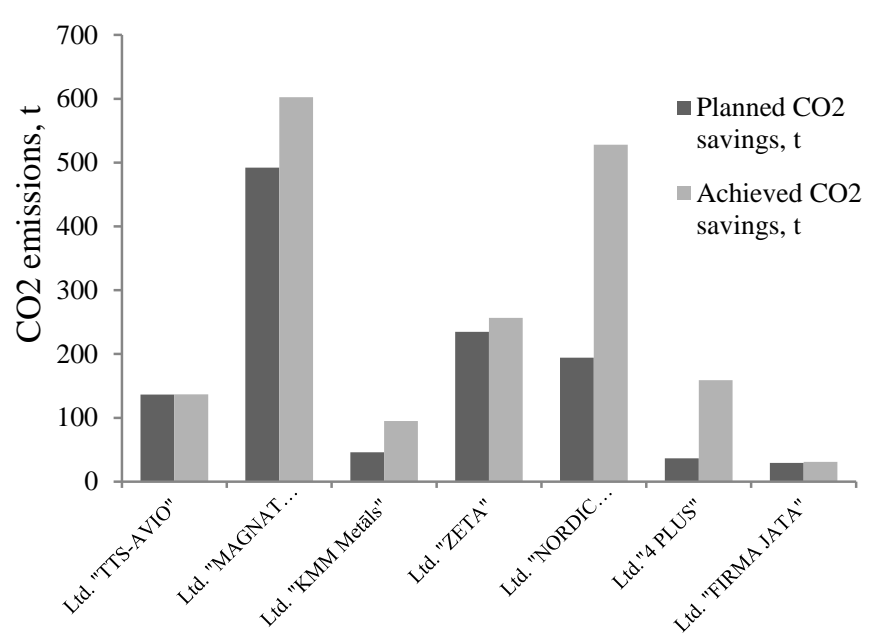

Fig. 2. Comparison of $\mathrm{CO} 2$ emissions saving

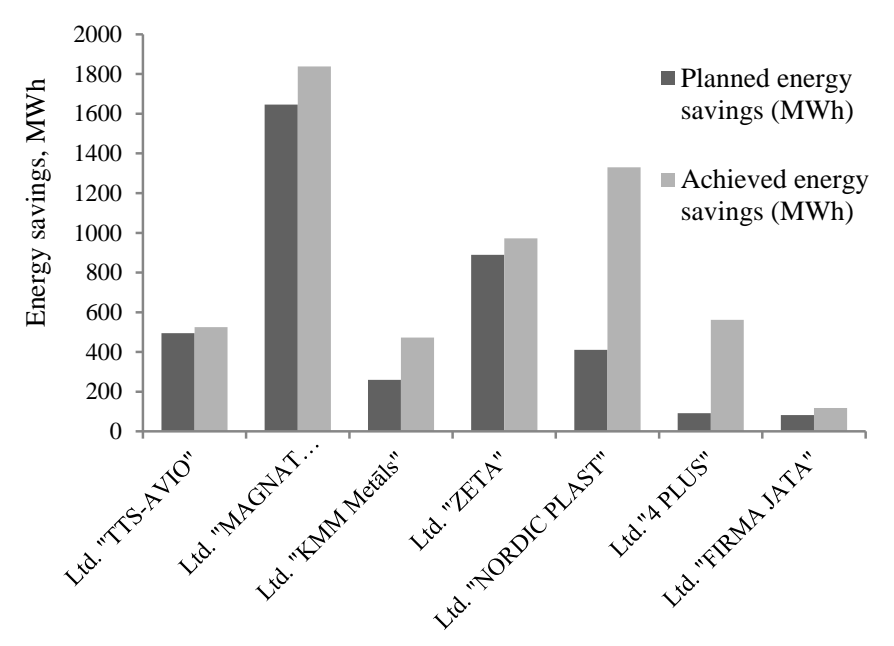

Fig.3. Comparison of energy saving

Furthermore, controls of the energy audits which were conducted before the implementation of energy efficiency measures were not carried out. It was not assessed how optimal and necessary are the measures and estimated energy savings. Differences between planned and achieved energy savings are usually $\sim 10 \%$. It would be necessary to analyze energy audit data and monitoring reports again in cases where the difference between is 3-5 times more. Data with wide variations is not appropriate for further use because it does not present objective results of effectiveness in a particular case. Thus it can be concluded that from the seven submitted monitoring reports for future research would be useful only three reports, where the difference between the planned and actually achieved energy savings is in the range of $6-12 \%$.

\section{The current energy savings by implementing projects}

The changes in energy savings compared to the energy saving target in the Second NEAP within the CFFI subprogram are shown in Figure 4 [1].

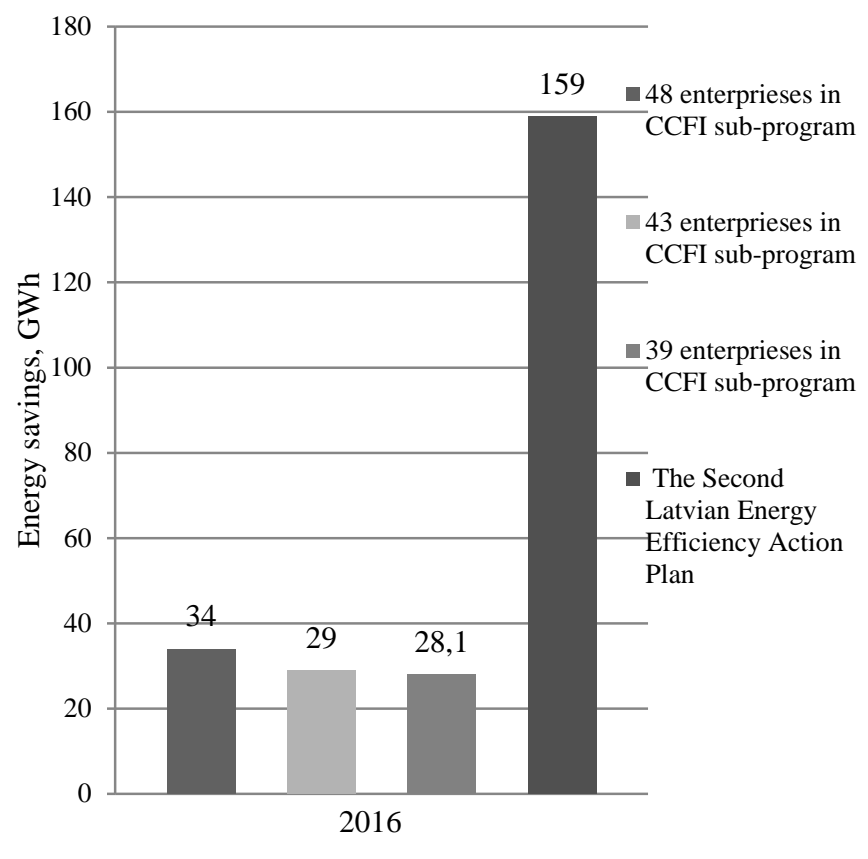

Fig. 4. Planned energy savings in the Second NEAP and the total planned energy savings in CCFI subprogram by 2016 [1]

The initial estimated energy savings were $34 \mathrm{GWh}$ if 48 enterprises implement all that was planned. Consequently, in 2012, 43 enterprises were involved in the subprogram. The energy savings of 43 enterprises could amount to $29 \mathrm{GWh}$. At the moment, the project is implemented and completed/almost completed in 39 enterprises, and the planned energy savings has reached only $28.1 \mathrm{GWh}$. There is still necessary $130.9 \mathrm{GWh}$ energy savings which is $82 \%$ of NEAP the target. This shows that it is necessary to introduce the second measure - voluntary agreement.

\section{VOLUNTARY AGREEMENT AS AN ENERGY EFFICIENCY SUPPORT POLICY INSTRUMENT}

Voluntary agreement is a long-term policy planning instrument for potential detection which is widely and successfully implemented in industry thoughout Europe. The Directive 2012/27/EU of the European Parliament and Council on energy efficiency have been attributed to the industrial sector. In the Directive 2012/27/EU, the attention is paid to ensure access to high quality energy audits for all end users. The Directive is promoting the factor to develop support programs for industry in European countries [12].

\section{A. The key conditions of the development of voluntary agreement}

By developing voluntary agreement it is necessary to evaluate the aims of the program aims and define execution tasks that promote achievements during the implementation phase. Specific and direct target definition promotes a positive end result. The choice of energy efficiency indicators is very important. Properly selected indictors can provide information to reach conclusions on whether the aim has been achieved, how far it is to attain the end. The indicator is a defining role. Best results can be obtained by 
selecting appropriate indicators. It is important to assess the potential benefits of reaching the goal and to know the cost efficiency during the program design stage. It is important to know how much capital is invested and how much of the invested money results in energy savings. The main participants in the program are: administrator, programs agent, the auditor, the client. The administrator is the creator of the program, most often energy department in the government. The program agent is responsible for the actions of the program and which is controlled by administrator. The auditors carry out energy audits and have the closest relationship with the customers. Usually auditor or client submits the energy audit to program agent [11].

Scandinavian countries - Sweden, Finland, Norway - have extensive experience in the development of voluntary agreements. Evaluating the Swedish, Norwegian and Finnish experience, one can observe some similarities between the three countries. All programs have state subsidised, one of the target groups were industrial enterprises and the agreement program was based on the principles of long-term agreements [11, 13, 14].

Comparing the costs effectiveness of the national energy efficiency programs, the most effective has been Energy audit program that was introduced in Finland. The costeffectiveness of the program was 0.009-0.011 eurocents/MJ. It was noted that one of the success factors was the proper subsidies (40-50\%) as well as the current situation in the country (companies wanted to reduce the cost of energy audits; many consultancy firms were looking for new job opportunities) contributed the effective action. The starting phase of the program where marketing activities (seminars, lectures) were carried out for the enterprises to provide information on options of the program was very important for the successful implementation of the program. This function was conducted by government agency Motiva. At the same time two more programs were implemented Voluntary agreement and Energy Service Company Program. These programs contributed companies to join the Energy audit program. This is the reason why it is difficult to distinguish each of the programs to know the exactly obtained energy savings for each program separately. Certified energy auditors and controls of energy audits provided quality results of energy audits and introduced energy efficiency measures were appropriate so the energy saving was achieved [14].

Evaluating the progress of implementation of the program in Norway, it was recognized that the beginning phase of the program was very successful and a large number of enterprises that wanted to participate in the program were attracted. The program was divided into two parts which were co-financed activities - energy management activities or in-depth research and advice on energy saving. Enterprises were able to apply and evaluate which of the proposed activities would be most appropriate for the enterprise. The positive fact of the program is the number of enterprises that were involved in the program. $63 \%$ of Norway's industrial sector enterprises were involved in the program. Participants of the program had a common website where it was possible to enter data and to compare energy savings with other enterprises that are in the same industry by using the benchmark method. There was achieved $6 \mathrm{PJ} / \mathrm{year}$ energy savings which is approximately $2 \%$ of the annual energy consumption in the industrial sector in Norway. Overall costeffectiveness was estimated to be $0.01-0.03$ eurocents/MJ. One of the success factors was the number of professional energy auditors. There were more than 80 energy auditors involved. The participants admitted that the program has improved their knowledge of energy efficiency measures and their implementation according to surveys that were carried out in the enterprises [14].

There was no energy efficiency program that was applied to SMEs until 2010 in Sweden. For this reason the Swedish program was based on the experience from the programs already implemented in Norway and Finland. The program was based on partly subsidized energy audits with long-term agreement elements. There were successfully selected subsidies which were $10 \%$ of annual energy costs in the enterprise. This was the optimal size that prompted companies to take part in the program. The energy savings were 700-1400 GWh/year. All the energy savings measures were not introduced. As a result cost-effectiveness was only 0.28 eurocents/MJ. If all energy efficiency measures were implemented cost-effectiveness would have been half of that -0.14 eurocents/MJ [11].

\section{B. Voluntary agreement in Latvia}

Voluntary agreement as a measure to reduce energy consumption in industry was included in the Second NEAP. The Cabinet of Ministers Regulation No. 555 “Agreements on Energy efficiency, promoting energy audits and energy management systems in industrial enterprises" entered into force on $15^{\text {th }}$ July, 2011. The agreement duration is five years (2011 - 2016). The aim of the agreement is to achieve at least $10 \%$ energy savings in the industrial sector, manufacturing sector or local authority. The voluntary agreement is concluded between the Ministry of Economy and associations of industry or individual industrial enterprises or local authorities. Each of the program participants need to create the Energy Efficiency Action Plan where energy reduction targets and planned energy efficiency measures are set. Each year the participants need to submit the monitoring report on the achieved results during the previous year to the Ministry of Economy. Effective development of agreement program and results would bring closer to the target of industrial sector that is $\sim 2 \%$ of the Latvian energy consumption in the industrial sector achievement. The developed Latvian program does not determine co-financing for energy audits or energy efficiency measures. Evaluating the experience of other countries it can be concluded that the Latvian program is not fully developed and the energy saving target for industrial sector more likely will not be achieved $[1,7,8]$.

Agreement program is based on a clear and specific goal. Neither the base year nor the future target which is to be 
achieved through the implementation of this regulation is defined. The responsible institutions and participants of the agreement program are also not defined - administrator, programs agent, the auditor, the client. The creator of the program is the administrator. The Ministry of Economy is the administrator in this case. Program agent who is responsible for the actions of the program is not mentioned. If the responsibility is not divided it may result in inefficient operation of the program. Therefore it would be necessary to clarify and distinguish the roles for each in the program. Not much attention is paid to marketing activities in the Latvian agreement program. There is only mentioned that the Ministry has the task to publish on the website in the official publication "Latvijas Véstnesis". There would be call to industry associations, enterprises or local authorities to conclude a bilateral agreement with the Ministry in its website on the internet. This is the only marketing activity to promote the agreement program. Given that there is no experience of implementation of the voluntary agreement in Latvia, then it is new for enterprises in Latvia. This is the reason why there should be more attention paid to organizing marketing activities as it was in case of Finland and Norway. Public awareness - seminars, discussions, contacting with the media and enterprises, is very important for successful implementation of a voluntary agreement program. There is no state financial support - subsidies - mentioned in the Cabinet of Ministers' Regulation [8].

\section{Improvements of Latvian voluntary agreement}

Latvian agreement program must be based on the principles of long-term agreements which would stimulate to achieve successful results of the program [11]:

- Energy Efficiency Action Plan;

- Publication of the results of energy audits;

- To submit monitoring reports at the end of the program.

An agreement program should be made like a system with components. The components move towards the system to the certain direction and stimulate to achieve the target of the program. The components are subordinate activities/instruments that contribute to the achievement of results (Fig. 5.).

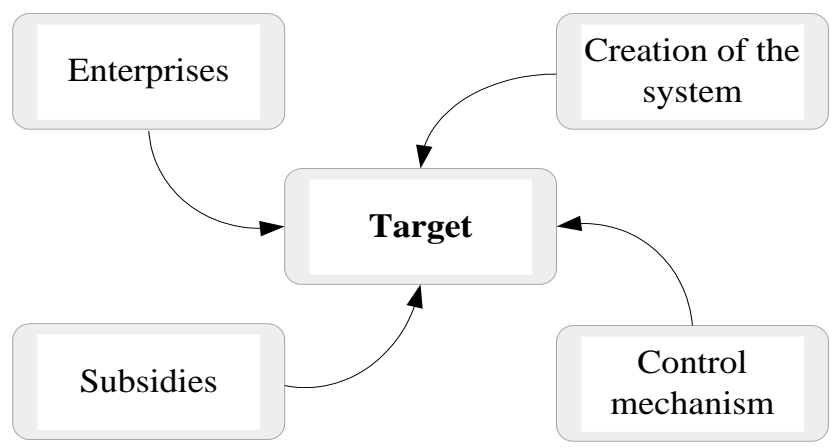

Fig. 5. The components of voluntary agreement.

A system should be created to manage the program and the responsible institutions for the successful introduction, implementation and achievement of results. While setting the target, there should be an evaluation on what the target should apply, which will be the clients - whether small and medium-sized industrial enterprises or large industrial companies or all enterprises in the industrial sector. It is possible to predict the optimal number of participants and to predict the desired results by identifying the target group. Stable and specific control mechanism promotes to achieve the program's objectives. The introduction of subsidies is an economically stimulating tool that will increase the number of program participants and the successful introduction of the program and its implementation.

\section{Development of the target}

The Cabinet of Ministers' Regulation No.555 states that the aim of the program is to reach at least $10 \%$ energy savings in the industrial sector, industry or local authority. In case of Latvia a focus group would be required for the development of the target. The focus group should consist of experts and specialists in industrial energy efficiency field as well as sectoral associations/organizations [8].

Each of the agreement program participants will need to develop their own energy efficiency action plan. If the whole program has an unclear target, then the participants will have problems to develop certain action plans. If from the beginning the program has a concrete goal, then it will be easier for the enterprise to define its target in the specific situation $[1,11,14]$.

Specificity is one of the well - established provisions of a target. Specific purpose can be developed by using the SMART target concept. The target should be specific, measurable, appropriate, realistic, and time-bound [15].

Specific. There should be chosen the client of the program during the target developing phase. At the moment the program is for industrial sector, industry or local authority. Each of them should have its own target because both energy consumption and processes that are related with energy consumption differ. If the program is concentrating on industrial enterprises the energy savings that could be achieved if the all participants in the program achieve $10 \%$ energy savings should be clarified. The target should define the optimal number of the enterprises that should be involved in the agreement program to achieve the target. For example, during the Norway agreement program there were involved $63 \%$ of Norwegian enterprises of the industrial sector which amounted about $2 \%$ of the energy savings from energy consumption in the industrial sector $[1,13]$.

Measurable. The energy consumption in the enterprises should be known in order to make the target measurable. Therefore there should be data collection to get to know the primary energy consumption. If the target is set $10 \%$ energy saving of "X"\% of industrial enterprises by summarizing collected data after implementing agreement program it would be possible to determine the results of the program.

Appropriate. The set target $159 \mathrm{GWh}$ energy savings of industrial sector ( $2 \%$ of annual energy consumption in the industrial sector) is appropriate. According to other country 
experience $2 \%$ of annual energy consumption in the industrial sector is achievable. At the moment there is still need of 130.9 GWh energy savings which is $82 \%$ of the industrial sector target $[1,13]$.

Realistic. It is realistic to achieve $10 \%$ of energy savings in each industrial enterprise that participate in an agreement program. There should be focus on a number of the enterprises that participate in the agreement program if the energy saving target is only $10 \%$ of energy savings in the industrial enterprise. Attracting a greater number of industrial enterprises would promote energy efficiency in the industrial sector and the awareness of the possible measures in the industrial enterprises would increase.

Time-bound. The agreement programs usually last 4 15 years referring to the experience of other countries. Now the target was set until 2016. The current situation already shows the target will not be achieved until 2016. It could be possible that during 2014 the Latvian agreement program will be improved. The program could be introduced starting with 2015 and the first energy savings could be reached between 2016 - 2017. It should be taken into account that the program would not show the real potential during the first two years. The agreement program must be a long-term program to achieve the planned results. The agreement program would be possible to implement not less than in 5 years. The set target could be achieved after 2016, if it is considered that the program is introduced in 2015.

- If the SMART target concept is used to define the target then it could be defined as follow: Achieve $10 \%$ of energy savings in " $X " \%$ of the industrial enterprises during the period $2015-2020$.

\section{E. The system and control mechanism of the program}

Administrator and agent of the program. The main responsible party of the program - the program administrator - is the Ministry of Economy. The program agent is not mentioned in the Cabinet of Ministers' Regulation No.555. The agent has one of the largest roles during the implementation of the program referencing to other country experience. Norway, Sweden, Finland had government agencies or specifically set up organizations that fulfilled the agent function. There also should be set up an agency or organization in Latvian case. If there an organization or agency is not set up, a situation can arise where the roles in the program is unclear. This kind of situation was in Norway. The roles and responsibilities were not clearly defined. As a result an organization Enova was introduced. The Latvian program agent could also be responsible for marketing campaigns to promote and introduce the public to the agreement program. Seminars and lectures for the potential program customers would introduce with the predictable results and cost effectiveness. It is important to contact with the media and disseminate the information about the agreement program [11, 13, 14].

The agent is responsible for coordinating collection and compilation of the monitoring data. Communicating with enterprises is essential. Additional reviews if monitoring data is collected would promote effectiveness of the program. That would avoid the situation that the monitoring reports are not submitted on time. Creating a web page would allow companies to submit monitoring reports at a distance and the supervision of the program would be easier. Such a site would enable enterprises to compare their data with others and that would create positive competition to reduce energy consumption.

The following should be implemented to complement the supervision of the program [11]:

- controls of the carried out energy audits and compliance of the results and energy efficiency measures;

- stricter control of monitoring data collection introducing controls twice a year;

- if the monitoring data is not submitted the agreement is not only broken but also there should be impose penalties

- if the energy savings are not achieved there should be penalties as well - the subsidies must be returned to program administrator.

The agent could be the Latvian Environmental Investment Fund, Latvian Energy Agency, Riga Energy Agency, Regional Energy Agency of Zemagale, or any other newly formed organization/agency with specialists whose expertise is energy efficiency in the industrial sector.

Regional energy centres/energy agencies should be involved to run the program more effectively and to facilitate the responsibilities for the agent program. This was the experience practised in the Scandinavian countries. Support centres provide better communication between the main program representatives and the clients of the program. Existence of the centres is crucial to improve the visibility of the program in the outermost regions of Latvia $[11,13,14]$.

Energy auditors. If the defined aim is to promote energy audits in the industrial sector then respectively there should be ensured the availability of energy auditors. For example, Finland has great experience in energy auditor training and certification. The certification was made especially for the agreement program. There were still differences between the quality of the energy audits despite the fact that all energy auditors had the same examination to receive the certificate. To minimize the difference there were inspections of the energy audits carried out to stimulate energy auditors to perform energy audits in the highest possible quality. There should be an attempt to implement this practice in Latvia. Only high-quality energy audits succeed with effective results. The agent could be responsible for the training and certification of energy auditors and control of energy audits [14].

\section{F. The program client}

If the program is concentrating on industrial enterprises, then it is necessary to know the positional number of clients to reach the target. The total number of industrial enterprises in 2010 in mining and quarrying and manufacturing was 6280. The energy consumption was $28.8 \mathrm{PJ} /$ year which is $90 \%$ of energy consumption in the industrial sector $[1,3]$. 
In total 11 Latvian industrial enterprises are included in the emissions trading system (ETS). The consumption of these enterprises is $\sim 5.6 \mathrm{PJ} /$ year. Therefore they should be covered by the voluntary agreement programme. Thus the total number of enterprises that may be involved in the agreement program is 6269 enterprises whose energy consumption is $23.2 \mathrm{PJ}$ [7].

By evaluating CCFI implemented subprogram, it can be concluded that the energy savings from implementing 39 projects is $28.1 \mathrm{GWh}$ if all enterprises reach their expected energy savings.

$$
Q_{\text {possible }}=Q-Q_{C C F I}=23.2-0.1=23.1 P J
$$

$\mathrm{Q}_{\text {possilbe }}$-the possible energy consumption of the enterprises that are the potential agreement program clients $(\mathrm{PJ})$; Q-energy consumption in mining and quarrying and manufacturing industry without enterprises that are under the ETS (PJ);

$\mathrm{Q}_{\mathrm{CCFI}}$-energy savings by implementing CCFI subprogram (PJ).

Consequently the energy consumption in manufacturing and mining and quarrying industry is $\sim 23.1 \mathrm{PJ}$.

The required energy savings to reach the set target of the Second NEAP is $126 \mathrm{GWh}$, which is 0.46 PJ. $20 \%$ of energy consumption in manufacturing and mining and quarrying industry is $4.62 \mathrm{PJ}$ which is about 1254 enterprises.

$$
Q_{\text {opt. }}=\frac{o_{\text {possible }} \times 20}{100}=\frac{23.1 \times 20}{100}=4.62 \mathrm{PJ}
$$

$\mathrm{Q}_{\mathrm{opt}}$-the optimal energy consumption in enterprises that could be involved in agreement program $(\mathrm{PJ})$;

These enterprises should be involved to achieve the Second NEAP target. The enterprises should achieve at least $10 \%$ energy savings that deals with $\sim 0.462 \mathrm{PJ}$.

$$
Q_{\text {agreem. }}=\frac{Q_{\text {opt. }} \times 10}{100}=\frac{4.62 \times 10}{100}=0.462 \mathrm{PJ}
$$

$\mathrm{Q}_{\text {agreem-energy savings by implementing agreement program }}$ $(\mathrm{PJ})$;

Involving $20 \%$ of the manufacturing and mining and quarrying enterprises it would be possible to achieve the specified energy saving target $[1,7,10]$.

It can be concluded that the target of the voluntary agreement program could be as follow: achieve $10 \%$ energy savings of $20 \%$ manufacturing and mining and quarrying enterprises during the period from 2015 to 2020.

\section{G. Subsidies}

The size and type of subsidies. Financial support is needed to achieve effective delivery. Partially subsidized energy audits (40-50\%) as well as partially subsidized (10-20\%) energy efficiency measures have shown the most positive results. Enterprises are motivated to invest in energy efficiency measures if the costs are partially subsidized and the payback time is 2-5 years. Therefore the assessment of the current situation in Latvian industry of what kind of subsidies should be granted is needed $[13,14]$.

Taking the Swedish experience, subsidies were granted to enterprises to carry out energy audits. The subsidies were granted to enterprises with an electricity consumption above $500 \mathrm{MWh}$ /year. The cost of energy in the enterprises was estimated at the average cost of electricity 40 euro/MWh. If the electricity consumption is $500 \mathrm{MWh} /$ year then the cost is 20000 euro/year. The size of the subsidies was estimated based on the cost of electricity per year which was $10 \%$ of the annual cost. Cases where the enterprise consumes $500 \mathrm{MWh} /$ year the resulting subsidies amounted to 2000 euro. This is roughly equivalent to the cost of energy audits for the industrial enterprise [34].

If the amount of the subsidy is calculated according to the Swedish example, then the current electricity prices in Latvia should be taken into account. The electricity tariff without VAT in 2012 was [47]:

- 83.86 eiro/MWh - large consumers;

- 109.18 eiro/ MWh - SMEs.

If the electricity consumption of the enterprise is $500 \mathrm{MWh} /$ year, then the average electricity costs account for 54780 eiro/year. $10 \%$ of the energy costs would be 5478 eiro. If it is assumed that there will be subsidized energy audits then there should be set rules on the next steps after carrying out the energy efficiency measures presented in energy audit. The enterprise should choose 2-3 most costeffective energy efficiency measures that will achieve $10 \%$ energy savings. Costs of energy efficiency measures should be funded by the enterprises.

In Finland there were two options for subsidies: 40-50\% of the energy audit costs or 10-20\% from costs of implementation of energy efficiency measure. In the first option the requirement for the enterprises was to carry the cost-effective measure. In other case the costs of energy audit were funded by enterprises [14].

Very often the energy efficiency measures are not the priority. Choosing subsidies for the implementation of energy efficiency measures would increase the number of involved enterprises. Subsidies for the energy efficiency measures would promote to carry out energy audits which are one of the objectives of the agreement program [14].

Supporting subsidies that are focused on reducing electricity consumption would contribute energy efficient in industrial processes which is the key aspect of energy efficiency in the industrial sector.

If subsidies are granted for both electricity and heat consumption, it may result in a majority of energy efficiency measures being related to building insulation. The resulting energy savings through building insulation will not contribute to a reduction of energy consumption resulting from the production process. This type of experience can be seen in the CCFI subprogram. If all 43 enterprises implement 
the planned measures then from the achieved energy savings $17.4 \%$ would be electricity savings and $82.4 \%$ thermal energy savings. From this it can be concluded that the majority of the planed measures were related to building insulation. If awarded subsidies would be extended only to electricity consumption, the implemented measures and energy savings would differ [10].

Therefore before making the decision on subsidies, it is important to review the existing situation and find out the most appropriate and cost effective solution.

\section{H. Implementation of voluntary agreement}

The Ministry of Economy is responsible for the preparation of the agreement program according to the Cabinet of Ministers' Regulation No.555. Their main task is to create a system with following requirements:

- creation of a focus group;

- analysis of the current situation in the industrial sector and determination of the potential energy savings;

- definition of a concrete target according to the analysis;

- nomination of the program agent that would be responsible for the further actions of the program introduction, implementation and result collection of the program.

Similar to the Finnish case, Latvia has to develop a sequential plan for the implementation of the agreement program. Each of the actions which must be addressed needs to have an indicator which is chosen to evaluate how well the operation is carried out (Table III).

According to the requirements of the Directive 2012/27/EU, the implementation of the Directive must be started by 15 June, 2014 (see Figure 6). To begin implementation, a focus group needs to be established, data collected, a database must be established, a target set and the agent of the program must be defined. The marketing activities should be launched from the beginning of the program. Training and certification of the energy auditors should be conducted in the first implementation years of the program because there will be increase of certified energy auditors. There is active program promotion from the beginning to attract enterprises. When carrying out energy audits, the control and implementation of energy efficiency measures occurs throughout the process. The first energy savings would be witnessed in those enterprises that were involved from the beginning of the program. The submission of the monitoring reports continues until the program is fully closed. The controls (professional review) of the monitoring reports also continue until the program is fully closed. Program evaluation and implementation of improvements should be performed after the first year of implementation of the program. It is necessary to remove the barriers to the successful implementation of the program [12].

All the activities that were described before are linked together and are making a scheme how the voluntary agreement is working (see Figure 7).

Figure 7 shows the relationships between the main participants in the program and the main activities that are related to each of the participants.

It is possible to create a successful policy instrument by establishing a common system, separating responsibilities and determining consecutive steps and plan. Voluntary agreement can be a successful program and could achieve the necessary energy savings for the industrial sector in Latvia.

\section{CONCLUSIONS}

At the moment there is no database which summarizes the energy consumption in Latvian industrial enterprises. The lack of such database makes it difficult to determine the current energy consumption in industrial enterprises and to find solutions for further energy consumption reduction. Sweden, Finland and Norway agreement programs have shown successful results. Programs were based on long-term agreement principles. Experience of Scandinavian countries would be appropriate to Latvian support policy programs. Programs have been extended to large enterprises and SMEs and the countries have several years of experience in such a program.

TABLE III

REVIEW OF ACTIVITIES AND INDICATORS

\begin{tabular}{|l|l|}
\hline \multicolumn{1}{|c|}{ Activity } & \multicolumn{1}{c|}{ Indicator } \\
\hline $\begin{array}{l}\text { Marketing program: } \\
\text { seminars, presentations and lectures } \\
\text { for the enterprises, communication } \\
\text { with the media }\end{array}$ & $\begin{array}{l}\text { Attendance of the seminars, } \\
\text { recognition of the agreement } \\
\text { program. }\end{array}$ \\
\hline $\begin{array}{l}\text { Trainings and certification of the } \\
\text { energy auditors }\end{array}$ & $\begin{array}{l}\text { The number of certificated energy } \\
\text { auditors }\end{array}$ \\
\hline $\begin{array}{l}\text { The enterprises get involved in the } \\
\text { program and receive the subsidies }\end{array}$ & $\begin{array}{l}\text { The number of the enterprises that } \\
\text { are involved in the program. }\end{array}$ \\
\hline $\begin{array}{l}\text { Carrying out energy audits in } \\
\text { enterprises. }\end{array}$ & $\begin{array}{l}\text { The number of controlled energy } \\
\text { audits and assessment of quality }\end{array}$ \\
\hline $\begin{array}{l}\text { Implementation of energy efficient } \\
\text { measures in the enterprises }\end{array}$ & $\begin{array}{l}\text { The number of energy efficient } \\
\text { measures and planned energy } \\
\text { savings }\end{array}$ \\
\hline $\begin{array}{l}\text { The enterprises submit monitoring } \\
\text { data reports to the agent }\end{array}$ & $\begin{array}{l}\text { The number of submitted } \\
\text { monitoring reports }\end{array}$ \\
\hline $\begin{array}{l}\text { Program agent carries out the } \\
\text { controls of the monitoring data } \\
\text { reports }\end{array}$ & $\begin{array}{l}\text { The quality of the monitoring } \\
\text { reports and the achieved energy } \\
\text { savings }\end{array}$ \\
\hline $\begin{array}{l}\text { The evaluation of the whole program, } \\
\text { cost efficiency }\end{array}$ & $\begin{array}{l}\text { Achieved energy savings on the } \\
\text { invested money in a unit (Ls/MWh } \\
\text { or } € / M W h)\end{array}$ \\
\hline
\end{tabular}


$2013 / 3$

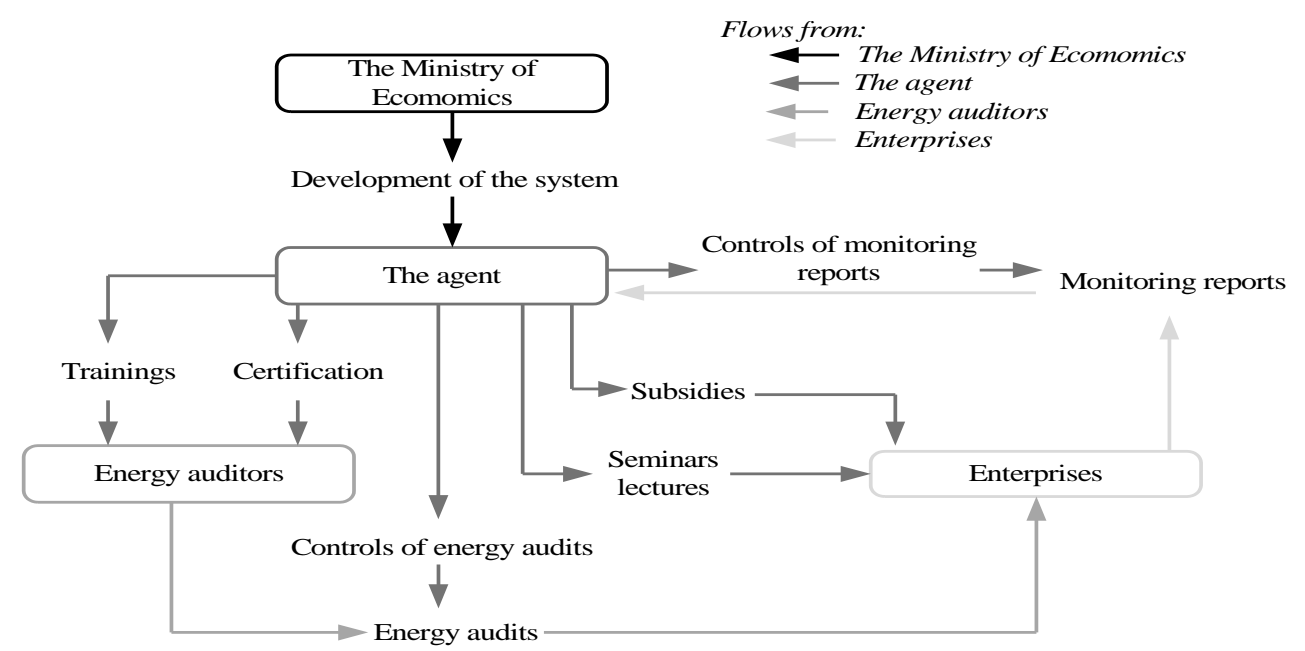

Fig. 6. A time frame of voluntary agreement implementation activities

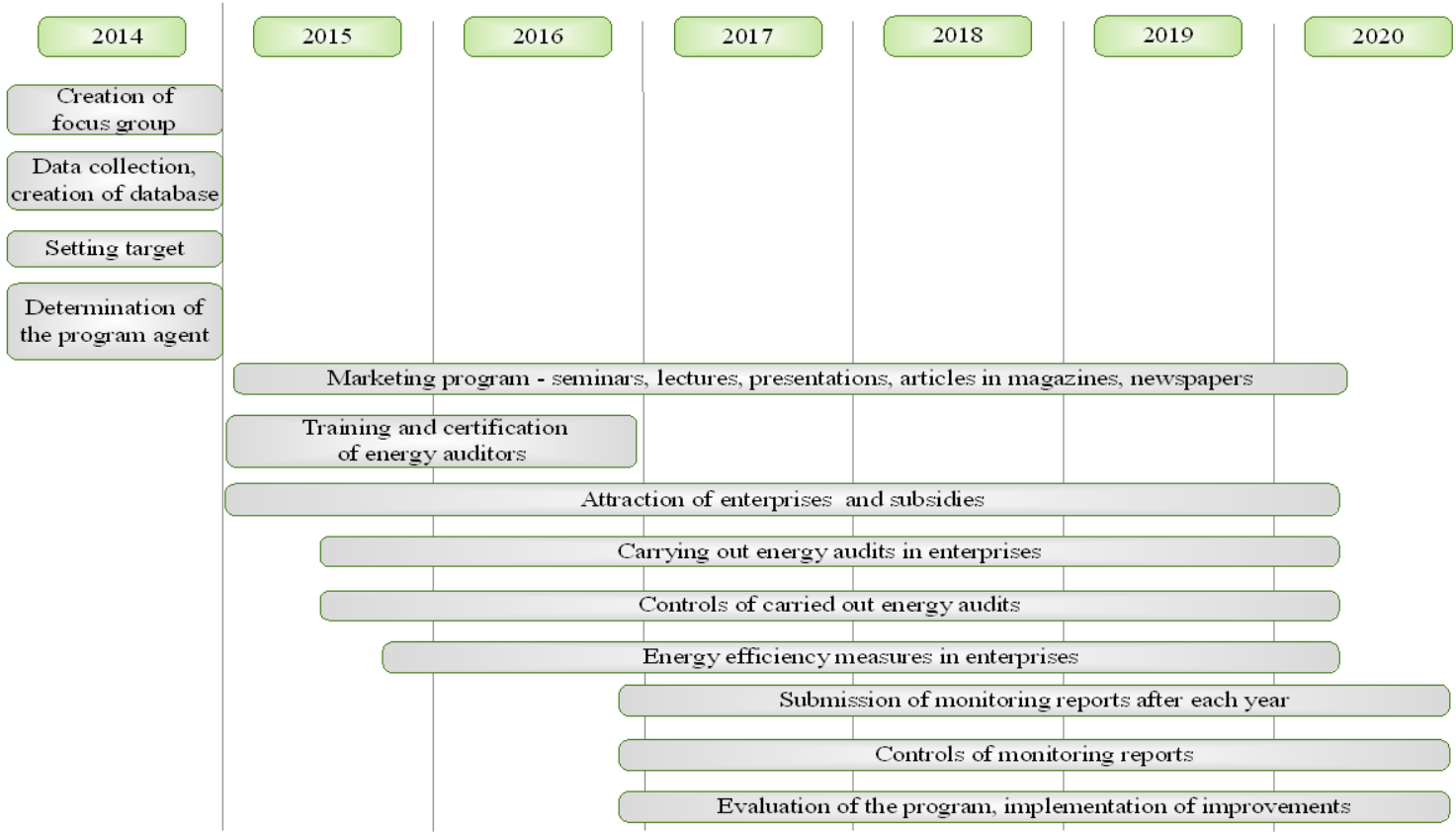

Fig.7 Scheme of voluntary agreement

CCFI subprogram "Complex solutions for reducing greenhouse gas emissions in industrial buildings" first submitted monitoring reports for the full year had $40 \%$ and higher energy savings achieved than planned. This might indicate that the incorrect data and calculations which were obtained before or after energy efficiency measures. The submitted data should be re-evaluated in order to determine the actual energy savings for energy efficiency measures. At the moment the CCFI sub-program is implemented in 39 enterprises. If all 39 implemented projects reach the expected energy savings the planned energy savings are 28.1 GWh. This is $18 \%$ of estimated energy savings in the Second NEAP. The savings should be achieved until 2016. Realizing only CCFI sub-program it can be concluded that the energy savings will not be achieved. There is a need to introduce other measures to improve energy efficiency. One of the priorities is voluntary agreement. The Ministry of Economics has determined that, with this program, the country should reach $130.9 \mathrm{GWh}$ or $\sim 82 \%$ of the energy savings target.
The introduced Cabinet of Ministers' Regulation No.555 is incomplete and should be improved. The set target will not be achieved by 2016 because voluntary agreement is a long-term policy planning tool. Experience of Scandinavian countries would be appropriate to Latvian support policy programs. Within the Latvian agreement program, it is needed to clarify the target, to establish a system that is responsible for overseeing the program, to define the control mechanism, to set a specific client of the program, to set the type and size of subsidies and to create a marketing program. To achieve the target of the Second NEAP for the industrial sector, $20 \%$ of manufacturing and mining and quarrying enterprises should be involved in the program and each enterprise must achieve $10 \%$ energy savings. By covering a great number of enterprises, it would be possible to achieve the target of industrial sector and to promote energy efficiency and corporate awareness of the possible measures would increase. 


\section{REFERENCES}

1. Ministry of Economics, Second Latvian Energy Efficiency Action Plan (2011-2013), Riga, 2011, Latvijas Vēstnesis, 2011, Nr. 148. / 4546.

2. Central Statistical Bureau of Latvia, Statistical classification of economic activities, [Accessed] 18.02.2013.]. Available: http://www.csb.gov.lv/node/29900/list

3. Central Statistical Bureau of Latvia, Economically active market sector statistical units, [Accessed] 20.02.2013.]. Available: http://www.csb.gov.lv/statistikas-temas/metodologija/ekonomiskiaktivie-uznemumi-37230.html

4. European Community, The new definition of SMEs User guide and model of declaration, Enterprise and industry publications, 2006

5. Central Statistical Bureau of Latvia, Number of industrial enterprises and group breakdown in Latvia,, [Accessed] 20.02.2013.]. Available: http://data.csb.gov.lv/DATABASE/uzreg/Ikgad\%C4\%93jie\%20statistik as\%20dati/01_skaits/01_skaits.asp

6. Tanaka, K. Review of policies and measures for energy efficiency inindustry sector. Energy Policy, 2011. Nr.39. 6532 - 6550p. http://dx.doi.org/10.1016/j.enpol.2011.07.058

7. Ozolina L., Rosa M. Review of energy efficiency policy and measures for industries in Latvia. Management of Environmental Quality: An International Journal, Nr. 23, 2012. 517 - 526p.

8. The Cabinet of Ministers regulations No. 555 “Agreements on Energy Efficiency, promoting energy audits and energy management systems in industrial enterprises", Latvijas Vēstnesis. - Nr. 109./4507. 201.

9. Climate Change Financial Instrument, [Accessed] 22.04.2013.] Available: http://kpfi.lv/modules/Konkurs/projekti.php?id=8\&lang=ly

10. Paturska A. Atbalsta politikas instrumentu izvērtējums energoefektivitātes paaugstināšanai rūpniecības sektorā Latvijāa. Bachelor thesis., Riga. 2012. - 64 p.

11. Thollander P., Dotzauer E. An energy efficiency program for Swedish industrial small- and medium-sized enterprises, Journal of Cleaner Production. - Nr. 18, 1339. - 1346 p, 2010

12. The Directive 2012/27/EU of the European Parliament and of the Council on energy efficiency. 2012

13. Modig G., Evaluation Of The Industrial Energy Efficiency Network In Norway, AID-EE. 2006

14. Khan J., Evaluation Of The Energy Audit Programme In Finland, AIDEE. 2006

15. Rietbergen M.G., Blok K. Setting SMART targets for industrial energy use and industrial energy efficiency, Energy Policy, Volume 38, Issue 8 4339-4354.p. 2010

16. Ministry of Economics, [Accessed] 02.05.2013.] Available: http://www.em.gov.lv/images/modules/items/EMInf_080113_cenas_4.p df

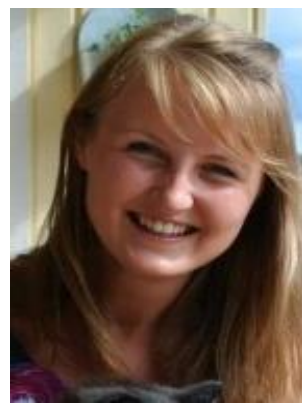

Kristīne Dobrāja, B.sc., Riga Technical University, Environment Protection and Heating Systems Institute, there she obtained Bachelor's degree in Environmental Science. Her thesis was: „Design of a Support Program for Energy Efficiency Improvement in Latvian Industry". She works in the Institute of Energy Systems and Environment, Riga Technical University from the year 2013. Kristine is a member of the "Association of Latvian Environmental Science Students".

Address: Kronvalda boulev.1, LV1010, Riga E-mail: kristine.dobraja@rtu.lv

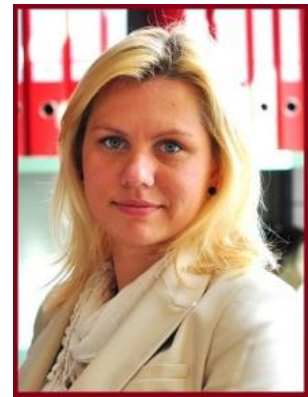

Liga Ozolina is a PhD student in the Institute of Energy Systems and Environment, Riga Technical University. Her main field of interest is energy efficiency policy in industry with main focus on voluntary agreements, benchmarking, and Energy Management System.

Address: Kronvalda boulev.1, LV1010, Riga, Latvia

E-mail: liga.ozolina@rtu.1v

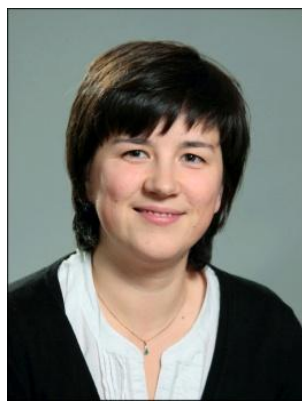

Marika Rosa, Dr.sc. ing., proffesor, Riga Technical University, Environmental Protection and Heating System Institute. Marika Rochas has been part of academic staff of Faculty of Energy and Electronics, Riga Technical University since 2003. The main research area are cleaner production and energy efficiency. She has participated in different local and international projects related to energy and environment. She has Doctor. $\mathrm{PhD}$ thesis "Analysis of mechanisms for $\mathrm{CO}_{2}$ emission reduction in Latvian energy installations" was defended in Faculty of Power and Electrical Engineering, Riga Technical University (2006). Address: Kronvalda Boulevard 1, Riga, LV-1010, Latvia E-mail: marika.rosa@rtu.lv 